\title{
THE IMPORTANCE OF FUNCTIONAL HEMISPHERIC ASYMMETRY IN THE ASSESSMENT OF COGNITIVE EVOKED POTENTIALS AND REACTION TIME
}

\section{AUTHORS}

Dejanović Mirjana ${ }^{1}$, Ivetić Vesna ${ }^{2}$, Nestorović Vojkan ${ }^{1}$, Milanović Zvezdan ${ }^{1}$, Parlić Dragica ${ }^{1}$, Smiljić Sonja ${ }^{1}$, Miletić Milanka ${ }^{1 .}$

${ }^{1}$ Department of Physiology, Faculty of Medicine, University of Priština, Serbia

${ }^{2}$ Laboratory of Neurophysiology, Department of Physiology, Faculty of Medicine, University of Novi Sad, Serbia

\section{CORRESPONDENT \\ MIRJANA DEJANOVIĆ \\ Department of Physiology, Faculty of Medicine, University of Priština, Kosovska Mitrovica, Serbia \\ $\triangle$ mirjana.dejanovic@gmail.com}

\section{SUMMARY}

The aim of this study was to determine whether there is a correlation of latency and amplitude of P300 cognitive potential and the degree of lateralization of brain hemispheres. The study included 60 subjects whose age was between 45 and 56 years. Bioelectric brain activity was recorded using argentum chloride $(\mathrm{AgCl})$ electrodes that were placed at central line of the scalp (over Fz and $\mathrm{Cz}$ regions) according to the international 10-20 standard. P300 was generated using "oddball" paradigm with randomized stimuli: A frequent $1000 \mathrm{~Hz}$ tone with an occurrence of $80 \%$ and a $2000 \mathrm{~Hz}$ tone (target) with a $20 \%$ occurrence. The measurement is done with the right hand (first recording) and left hand (second recording). All subjects in this study were tested for usage lateralization and showed that they are right-handed. Based on the results of gestural lateralization subjects are divided in three groups. In the group with high degree of lateralization latencies of P300 were significantly lower when dominant hand was used in comparison to non-dominant hand, on Fz electrode $(t=4,162, p<0,01)$ and $C z$ electrode $(t=5,302, p<0,01(p<0.01)$ and amplitudes of P300 were significantly higher, on Fz electrode $(t=-2,725, p<0,05)$, on Cz electrode $(t=2,527, p<0,05)$. However, there were no statistically significant differences $(p>0.05)$ for latencies and amplitudes of P300 between dominant and non-dominant hand for the group of subjects with weak and average degree of lateralization. In both subject groups, significantly faster RT was measured when dominant hand was used. The P300 cognitive potential and reaction time can contribute to the study of indicators of the functional hemispheric asymmetry of the brain.

Keywords: P300, ERP, Reaction time, functional asymmetry

\section{INTRODUCTION}

The functional asymmetry of the hemispheres implies that there are differences in the organization of the left and right cerebral hemispheres, as well as in the types of function for which they are specialized [1]. Modern neurophysiological studies have replaced the concept of cerebral dominance and superiority of one hemisphere with the concept of a complementary hemispheric specialization [2]. It is well known that there are different divisions in hemispheric specialization of functions. It is believed that the left hemisphere is more successful on language, phonetic analysis and motor functions, the so called categorical hemisphere, while the right one is more successful in processing on the visuospatial functions, prosody and attention components nonverbal and visual-spatial information, and is thus called representative hemisphere [3]. The left hemisphere processes the information sequentially, by seeking differences among things, breaking the whole into separate parts and observing details, which makes it characteristically analytic. The right hemisphere processes the information simultaneously, by seeking similarities between things, synthesizing, and considering the whole, which makes it characteristically synthetic. Also, the right hemisphere plays an important role in face recognition. most of the functions of the brain is based on cooperation between the two hemispheres. Despite the differences, it is important to emphasize that the majority of brain function is based on the cooperation between the two hemispheres [4]. In other words, one hemisphere is dominant in certain aspects of a single function, and the other is dominant in the other forms of the same function. For example, the left hemisphere in most individuals is dominant in speech comprehension and verbal expression programming. On the other hand, the right hemisphere is dominant in prosody (melody, rhythm of speech) and in the understanding of the affective and emotional components of speech.

An indispensable way of exploring the hemisphere laterality is the measurement of brain activity during a spontaneous or task-oriented activity. Some of these methods are electroencephalography (EEG) and evoked potentials. Different modalities of evoked potentials are important in the analysis of cerebral asymmetry but their true value can be seen in combination with the results of 
clinical and other complementary tests. More recent research in methodology includes the P300 component of the cognitive evoked potentials. The numerous clinical P300 studies [5-9], clearly indicate that this component can serve as an indicator of cognitive function. However, the results of a few previous ERP studies that have examined the relationship hemispheric lateralization and cognitive status have shown controversial results.

Some studies suggested that a larger degree of hemispheric lateralization is associated with better performance $[10,11]$. On the other hand, some studies found negative correlations or no correlation between the degree of laterality and performance [12,13].

However, these studies did not evaluate the effects of the degree of laterality on the P300 wave and reaction time. It remains unclear whether is advantageous to be strongly or weakly lateralized, when one considers actual performance of cognitive tasks?

\section{STUDY OBJECTIVE}

The purpose of this study was to investigate the influence of the degree of laterality on the amplitude and latency of the P300 component and reaction time. The aim of the research is in line with current interest in neurophysiology, which is focused on testing the P300 ERP parameters as one of the possible indicators of functional asymmetry of the cerebral hemispheres.

\section{MATHERIAL AND METHODS}

The study included 60 healthy right-handed subjects (30 men and 30 women, mean age $51 \pm 2.7$ years, range 45-56 years). The health condition of the subjects was anamnestically assessed to rule out the possible existence of neurological and other disorders, as well as the consumption of drugs or any other substances that could affect brain function. All the tests were conducted in the morning hours, in the neurophysiological laboratory of the Department of Physiology, the Faculty of Medicine in Novi Sad, on the well rested subjects. Prior to participating in the trial the subjects did not take any psychoactive substances such as coffee, tea or alcohol. The usage and gesture laterality was defined in all the subjects.

Čordić and Bojanin test, with 10 separate testings, was used for the evaluation of the usage laterality. The subjects demonstrated the activities they perform everyday - writing, combing hair, eating, striking a match, holding a broom, etc.

Gestural laterality was assessed by Berges trials. The dominant hand is always the upper one. The righthandedness is clearly manifested if the right-hand side prevailed in more than six trials $(R / L=9: 0,8: 1,7: 2)$. It is a highly pronounced degree of laterality. If it manifests in the 6:3 and 5:4 ratio, then it is a low or moderately pronounced degree of laterality. An informed consent was obtained from all subjects, before they were enrolled into the study.

\section{ERP MEASUREMENT}

P300 ERPs were recorded using the classic auditory oddball paradigm [14] with $20 \%$ of target and $80 \%$ of non- target stimuli. Tones with the frequency of $2000 \mathrm{~Hz}$ and $1000 \mathrm{~Hz}$ and strength of $90 \mathrm{~dB}$ were used as a target and non-target stimuli. Tones were presented to the subject trough binaural phones. The subjects were instructed to react as fast as possible to the target tones $(2000 \mathrm{~Hz})$ by pressing the button on the special handle they were holding in their dominant hand first registration, nondominant hand second registration and at the same time to ignore rhythmical non-target tones $(1000 \mathrm{~Hz})$. The subjects were sitting on the chair in the comfortable position in the silent darkened room with their eyes open.

Bioelectrical activity of the brain was recorded using $\mathrm{Ag} / \mathrm{AgCl}$ electrodes fastened on the scalp of the subject with the colodium. Two active electrodes were positioned at the central line of the scalp frontally $(\mathrm{Fz})$ and centrally $(\mathrm{Cz})$ according to the international $10-20$ system. Reference electrodes were placed at the mastoids while the ground electrode was positioned at the subject forearm. Impedance of all electrodes in all recordings was under $5 \mathrm{k} \Omega$. Tone order is determined by a random number generator individually for each recording. The signal was averaged during the recording. The cortical activity signal averaging was done separately for target and non-target stimuli. At the end of the recordings P300 latency was identified as the largest positive peak at range 250-450 ms occurring after the N1, P2 and N2 ERP components obtained from the "target" stimulus presentation. The peak amplitudes $(\mu \mathrm{V})$ were evaluated as the differences between P300 peak and the mean baseline automatically calculated by a computer.

\section{STATISTICAL ANALYSIS}

In statistic analysis the following parameters of descriptive statistics were used: arithmetic mean, standard deviation, minimal and maximal values. For testing the significant of arithmetic mean difference the Student's t test was used. Kolmogorov-Smirnov test was used for assessing normality. In the interpretation of data, probability values of $p<0.05$ (two tailed) were considered statistically significant. The statistical analysis was performed, using $\mathrm{R}$ version 3.1.0 [15].

\section{RESULTS}

All subjects in this study were tested for usage lateralization and showed that they are right-handed. Based on the results of gestural lateralization subjects are divided in three groups (Graph 1): Group I - the group with the highly pronounced degree of laterality. Group II - the group with low and moderately pronounced degree of laterality and Group III - the group with retrained laterality. Kolmogorov test did not show that the distribution of the obtained values significantly differs from the normal (Gaussian) distribution and the results were analysed by parametric methods.

We compared the latencies and amplitudes of P300 in subjects between the first recording (the handle is held in the dominant hand) and the second recording (the handle is held in the non-dominant hand). With the usage of the dominant hand P300 latencies were significantly shorter over the Fz electrode $(t=4.162, p<0.01)$, as well as on $\mathrm{Cz}$ electrode $(\mathrm{t}=5.302, \mathrm{p}<0.01)$. See Graph $2 a$. 
Graph 1. Subject distribution based on gestural lateralization: highly pronounced degree of laterality (group I),

low and moderately pronounced degree of laterality (group II), retrained laterality (group III) $3.45 \%$

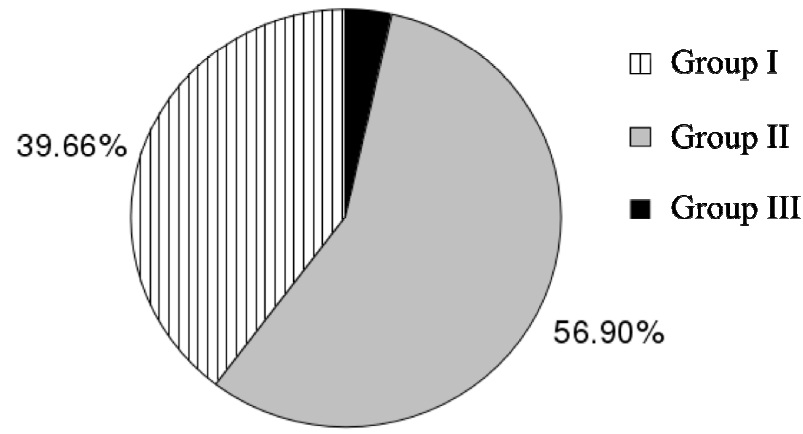

By analysing the results of P300 amplitudes in the group with a highly developed degree of laterality, it was observed that there was a statistically significant difference between first recording and the second recording on the Fz electrode $t=-2.725, p<0.05)$, and $\mathrm{Cz}$ electrode $(t=2.527, p<0.05)$. See Graph 3a.

The subjects with high degree of lateralization had the mean RT and standard deviation of $283.5 \pm 4 \mathrm{~ms}$ when dominant hand was used and $309.1 \pm 6 \mathrm{~ms}$ when non-dominant hand was used. The mean value of reaction time was statistically shorter with the usage of the dominant hand compared to the non-dominant (Graph 4a).
We analysed the P300 latency and amplitudes in the second (II) group with low and moderately pronounced level of laterality and compared the dominant and nondominant hand (Table 2).

The results of P300 latency in the group with the low and moderately pronounced level of laterality showed that there was no statistically significant difference between first and second recording in either of the observed distribution areas $(\mathrm{t}=0.381, \mathrm{p}>0.05, \mathrm{t}=$ $0.818, p>0.05)$. See Graph 2b. P300 amplitudes of the cognitive waves did not significantly differ in relation to the hand that was used, on Fz electrode $(t=-0.464$, $p>0.05)$, as well as on $\mathrm{Cz}$ electrode $(t=-1.406, p>0.05)$. See Graph 3b.

The subjects with low and moderately pronounced level of laterality had the mean RT and standard deviation of $303.3 \pm 6 \mathrm{~ms}$ when dominant hand was used and $324.6 \pm 8 \mathrm{~ms}$ when non-dominant hand was used. The reaction time was significantly lower with the usage of the left hand. (Graph 4b).

By analyzing the results of the $\mathrm{P} 300$ parameters in the group with a highly developed degree of laterality we observed that there was statistically significant difference in the values of P300 latencies $(p<0.01)$ and P300 amplitude $(p<0.05)$ in relation to the hand that was used. On the other hand, no statistically significant difference was observed in the P300 latencies and amplitudes between the dominant and non-dominant hand in the group with the low and medium pronounced degree of laterality, or in the group with retrained laterality.

Table 1. alues of P300 latencies and amplitudes and reaction time in group I

\begin{tabular}{|c|c|c|c|c|c|c|c|c|c|c|}
\hline \multicolumn{5}{|c|}{ Latency P300 [ms] } & \multicolumn{3}{|c|}{ Amplitude P300 $[\mu \mathrm{V}]$} & & \multicolumn{2}{|l|}{ RT [ms] } \\
\hline Electrode & & & & & & & & & & \\
\hline Hand & right & left & right & left & right & left & right & left & right & left \\
\hline$\overline{\bar{X}}$ & 314 & 335,96 & 320,26 & 345 & 15,11 & 11,87 & 12,69 & 10,64 & 283,52 & 309,09 \\
\hline SD & 24,46 & 26,9 & 26,80 & 30,68 & 6,64 & 8,02 & 7,18 & 6,29 & 47,38 & 60,74 \\
\hline
\end{tabular}

(RT- reaction time, $\bar{X}$ - mean value, SD - standard deviation)

Table 2. Values of P300 latencies and amplitudes and reaction time in group II

\begin{tabular}{|c|c|c|c|c|c|c|c|c|c|c|}
\hline \multicolumn{5}{|c|}{ Latency P300 [ms] } & \multicolumn{4}{|c|}{ Amplitude P300 $[\mu \mathrm{V}]$} & \multicolumn{2}{|c|}{ RT [ms] } \\
\hline Electrode & & $\mathrm{z}$ & & & & & & $\mathbf{z}$ & & \\
\hline Hand & right & left & right & left & right & left & right & left & right & left \\
\hline$\overline{\bar{X}}$ & 330,94 & 332,33 & 335,52 & 339,3 & 10,43 & 9,9 & 10,15 & 8,76 & 303,33 & 324,6 \\
\hline SD & 22,45 & 22,82 & 24,3 & 26,51 & 6,05 & 8,45 & 5,88 & 6,03 & 53,19 & 56,13 \\
\hline
\end{tabular}

(RT- reaction time, $\bar{X}$ - mean value, SD - standard deviation)

Graph 2. Average P300 latency values using dominant and non-dominant hand on Fz and Cz electrode in group I (a) and group II (b)

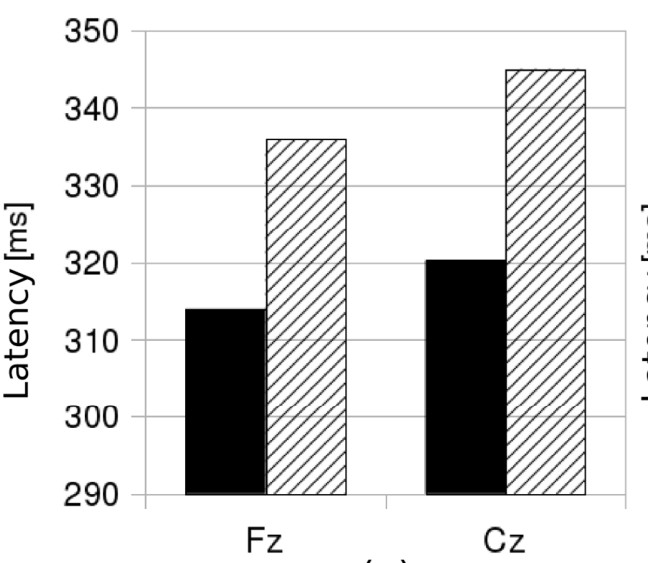

(a)

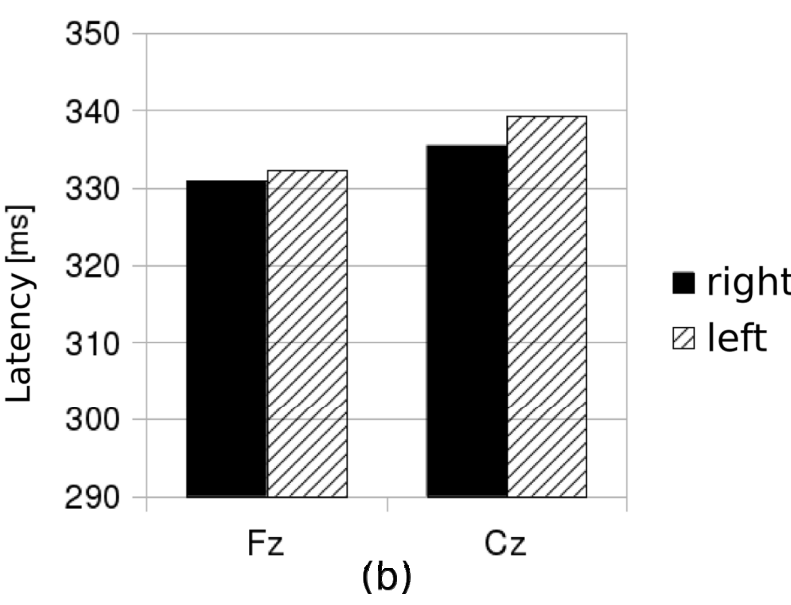

$2016 ; 45(2) 77-82$ 
Graph 3. Average P300 latency values using dominant and non-dominant hand over frontal (Fz) and central (Cz) brain areas in group I (a) and group II (b)

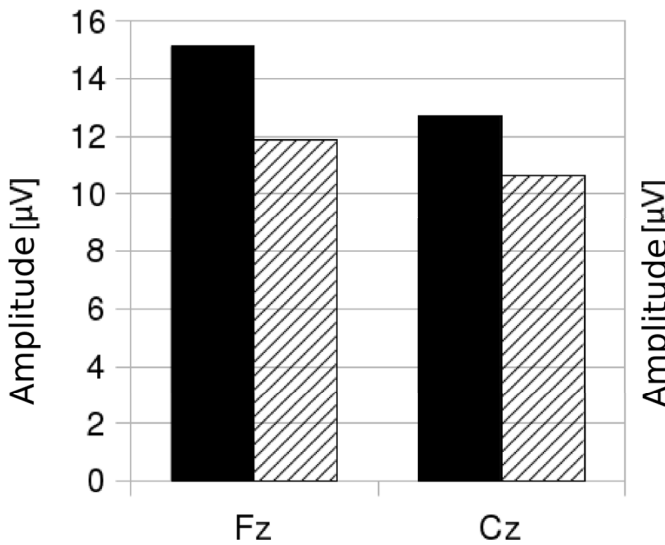

(a)

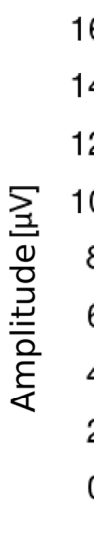

$$
\begin{array}{r}
16 \\
14 \\
12 \\
10 \\
8 \\
6 \\
4 \\
2 \\
0
\end{array}
$$

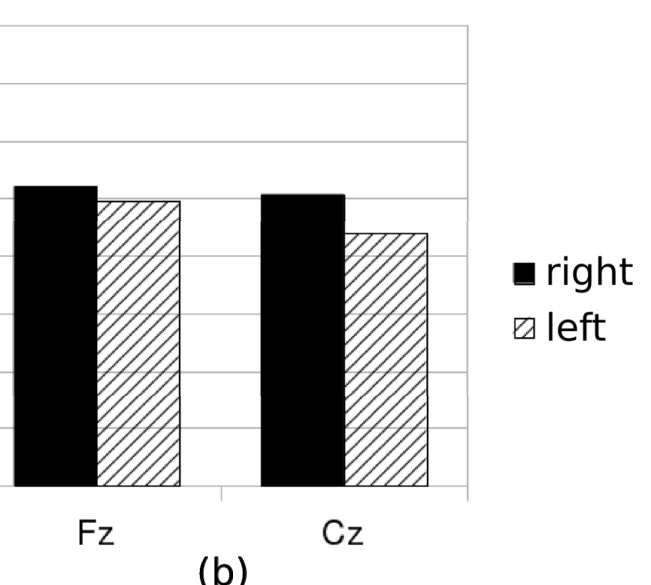

Graph 4. Average values of reaction time with dominant and non-dominant hand in group I (a) and group II (b)

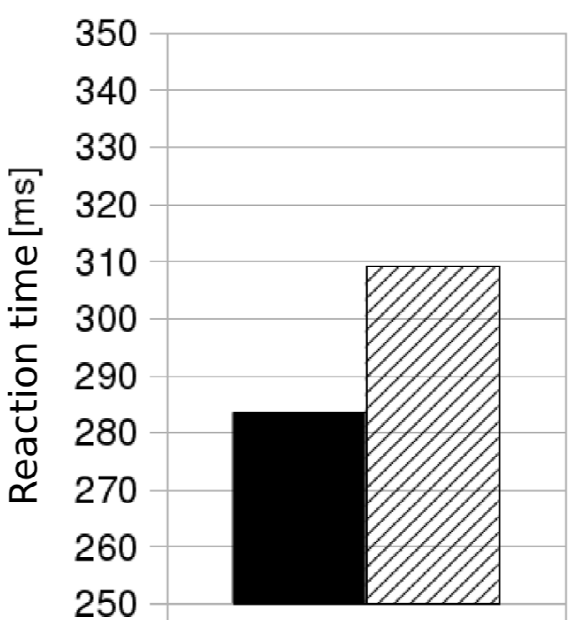

(a)

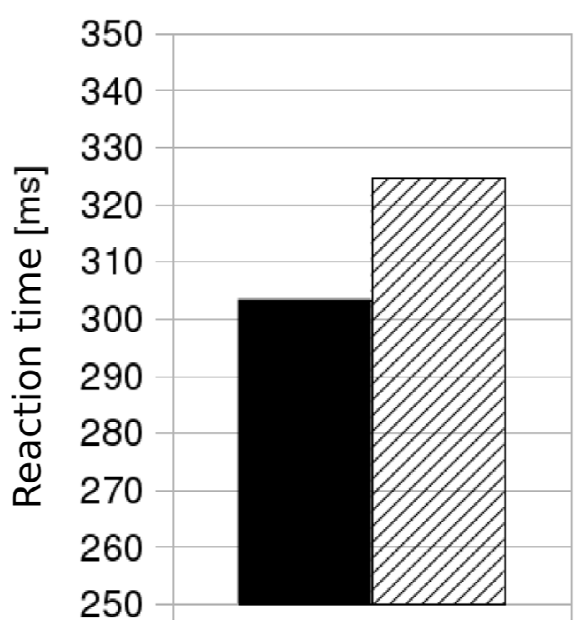

(b)

\section{aright gleft}

\section{DISCUSSION}

Dominant laterality is an important indicator of the integrative activity of the cerebral cortex in terms of dominance of one hemisphere. The dominance of a cerebral hemisphere is predetermined by the biological structure of the central nervous system, which is considered to be genetically determined [16]. Today the mosaic dominance function of the cerebral cortex is only partially discovered, as some of the functions are organized through the dominance of the left and some through the dominance of the right hemisphere.

In this study, the registration of P300 evoked potentials and the analysis of its variables, latency and amplitudes was used in an attempt to tests manifestations of functional asymmetry of the cerebral cortex in subjects who are, according to their usage laterality, righthanded, but with different levels of gestural laterality. It is well known that the hemispheric laterality in righthanded people is much more pronounced, and that the side of the body that is more frequently used is usually more developed. This is evident for the right-handed subjects while for the left-handed subjects the two sides of the body are more symmetrical $[17,18]$. The results obtained in this study clearly showed that the mean latency of the P300 cognitive potential is dependent on the degree of laterality manifested by gestural laterality. The comparison of the P300 latencies in subjects from different groups indicates that the subjects with a highly pronounced degree of laterality had significantly shorter P300 latencies, compared to the subjects with moderately pronounced degree of laterality as well as to the subjects with retrained left-handedness.

These results suggest that the latency of the cognitive P300 wave could be considered as an indicator of functional asymmetry of hemispheres. In support of this view, the results show that the latencies of the P300 waves for the strongly right-handed subjects were significantly shorter when using the right rather than the left hand. On the other hand, this difference was not significant in subjects with moderate and retrained laterality. This means that with the higher degree of functional hemispheric asymmetry, i.e. when the gestural laterality is more pronounced, latency of P300 waves becomes shorter and there are more significant differences in P300 latencies between the left and the right hand. The fact that the differences between the P300 latencies of the right and the left hand are positively correlated with the increase in the degree of dominance of the 
cerebral hemispheres, speaks in favor of the influence of the dominant cerebral hemisphere on the P300 latencies.

In the interpretation of these results we must take into account that it is now considered that the P300 latency reflects the speed of the stimulus classification based on the differentiation between two events when there is an accommodation (or the adjustment) of the mental model of structure and the stimulus to the current state, and the variations of $\mathrm{P} 300$ amplitude are related to the amount of information the given stimulus caries [19].

The current literature has accepted the hypothesis that the variations in the amplitudes of the P300 waves reflect the redirection of attention capacity, while the variations in the latencies of the P300 waves reflect the rate at which these capacities are redirected. It should be noted that the P300 latency is independent of the response selection process and is not directly and necessarily linked to the behavioral indicators such as the reaction time.

From all this we can conclude that with a higher degree of dominance the specialized hemisphere demonstrates the higher speed of stimuli classification, the faster reorientation of attention (P300 latency) and the more significant differences between left and right. On the other hand, the attention capacity and the speed of the redirection of this attention, which are reflected in the P300 amplitude and latency, are positively correlated with the degree of hemispheric dominance that is there are fewer or no differences between the right and the left side when the degree of hemispheric dominance is lower.

The attention process itself consists of two levels that interact with the hemispheric specialization. One of them is the selection process that manages the distribution of cognitive capacities, and other is the activation process (arousal), which determines the amount of the available capacity. These two factors are interdependent and affect one another. A higher degree of laterality and the variability of asymmetry result from the fluctuation of attention, so that the hemisphere with the increased level of attention becomes perceptually selective re- garding the stimuli coming from the contralateral side of the body and increases its capacity for processing them. The subjects directed their attention when the stimulus was unpredictable (the "oddball paradigm"), and prior knowledge of the type of the stimuli can activate the hemisphere responsible for their processing. The expectation of a certain kind of stimulus can enable a preselection of the appropriate processing strategies, or increase the level of general activity (arousal) of the appropriate hemisphere.

The results of the reaction time in our study show that the reaction time (RT) was shorter in all of the observed groups in the usage of the right hand, which is consistent with the results of the other studies on healthy subjects which analyzed the RT as a parameter that reflects the flow velocities of neurophysiological, cognitive and information processes that occur due to the effect of the stimulus on the subjects' sensory system.

\section{CONCLUSION}

The components of the P300 cognitive potential can contribute to the study of indicators of the functional hemispheric asymmetry of the brain. The subjects with a highly pronounced degree of laterality had statistically significant differences in P300 latencies and amplitudes in relation to whether the dominant or non-dominant hand was used, but these differences could not be found in subjects with moderate and low levels of hemispheric dominance.

The reaction times were significantly shorter when the dominant hand was used, in all of the subjects.

\section{REFERENCES}

1. Bourne VJ. Lateralised processing of positive facial emotion: sex differences in strength of hemispheric dominance. Neuropsychologia. 2005; 43(6): 953-6.

2. Cai Q, Van der Haegen L, Brysbaert M.Complementary hemispheric specialization for language production and visuospatial attention. Proc Natl Acad Sci USA. 2013; 110(4): E322-30.

3. Davidson R.J. (1984). Affect, cognition, and hemispheric specialization . In : C.E. Izard, J. Kagan, \& R. Zajonc (Eds.), Emotions, cognition and behavior. Cambridge University Press. 1984; 320-365.

4. Kosslyn SM, Gazzaniga MS, Galaburda AM, Rabin C. Hemisferic Specialization. In Zigmund M.J, Bloom FE, Landis S.C, Roberts J.L, Squire L.R. Fundamental Neuroscience. Academic press. 1999; 1521-42.

5. Bennys K, Portet F, Touchon J, Rondouin G. Diagnostic value of event-related evoked potentials N200 and P300 subcomponents in early diagnosis of Alzheimer's disease and mild cognitive impairment. J Clin Neurophysiol. 2007; 24: 405-412.

6. Frodl T, Hampel H, Juckel G, Bürger K, Padberg F, Engel RR, Möller HJ, Hegerl U. Value of event-related P300 subcomponents in the clinical diagnosis of mild cognitive impairment and Alzheimer's Disease. Psychophysiology. 2002; 39(2): 175-181.

7. Golob EJ, Irimajiri R, Starr A. Auditory cortical activity in amnestic mild cognitive impairment: relationship to subtype and conversion to dementia. Brain. 2007; 130: 740-752

8. Golob EJ, Johnson JK, Starr A. Auditory event-related potentials during target detection are abnormal in mild cognitive impairment. Clin Neurophysiol. 2002; 113: 151-161. 
9. Irimajiri R, Golob EJ, Starr A. Auditory brain-stem, middle- and long-latency evoked potentials in mild cognitive impairment. Clin Neurophysiol. 2005; 116: 1918-1929.

10. Bach S, Brandeis D, Hofstetter C, Martin E, Richardson U, Brem S. Early emergence of deviant frontal fMRI activity for phonological processes in poor beginning readers. Neuroimage. 2010; 53(2): 682-693.

11. Chiarello C, Welcome SE, Halderman LK, Leonard CM. Does degree of asymmetry relate to performance? An investigation of word recognition and reading in consistent and mixed handers. Brain Cogn. 2009; 69(3): 521-530.

12. Lust JM, et al. Driving performance during word generation-testing the function of human brain lateralization using fTCD in an ecologically relevant context. Neuropsychologia. 2011; 49(9): 2375-2383.

13. Van Ettinger-Veenstra HM, Ragnehed $M$, Hällgren $M$, Thomas Karlsson $T$, Landtblom AM, Lundberg $P$, Engström M. Right-hemispheric brain activation correlates to language performance. Neuroimage. 2010; 49(4): 3481-3488.

14. Duncan C, Barry R, Connolly J, Fischer C, Michie P, Näätänen R, Polich J, Reinvang I, Petten C. Event-related potentials in clinical research: Guidelines for eliciting, recording, and quantifying mismatch negativity, P300, and N400. Clin Neurophysiol 2009: 1883-908.

15. R Core Team R. A language and environment for statistical computing. R Foundation for Statistical Computing, Vienna, Austria. Version 3.1.0 (2014-04-10). URL http://www.R-project.org/

16. Annett $M$. Hand preference observed in large healthy samples: classification, norms and interpretations of increased non-righthandedness by the right shift theory. Br J Psychol. 2004; 95: 339-53.

17. Pulves D, White LE, Andrews TJ. Manual asimetry and handedness, Proceedings of the National Academy of Science USA. 1994; 91(11): 5030-2.

18. Sommer IE, Aleman A, Somers M, Boks MP, Kahn RS. Sex differences in handedness, asymmetry of the planum temporale and functional language lateralization. Brain Res 2008; 1206: 76-88.

19. Fjell AM, Walhovd K: P300 and neuropsychological tests as measures of aging: scalp topography and cognitive changes. Brain Topog. 2001; 14(1): 25-40.

\section{SRPSKI}

\section{ZNAČAJ FUNKCIONALNE ASIMETRIJE HEMISFERA MOZGA U PROCENI KOGNITIVNO EVOCIRANIH POTENCIJALA I VRE- MENA REAKCIJE}

Dejanović Mirjana1, Ivetić Vesna², Nestorović Vojkan", Milanović Zvezdan ${ }^{1}$, Parlić Dragica ${ }^{1}$, Smiljić Sonja ${ }^{1}$, Miletić Milanka ${ }^{1}$

${ }^{1}$ Medicinski fakultet Univerziteta u Prištini, Srbija

${ }^{2}$ Laboratorija za neurofiziologiju, Medicinski fakultet, Univerzitet u Novom Sadu, Srbija

\section{SAŽETAK}

Cilj istraživanja je bio da se utvrdi da li postoji povezanost stepena lateralizovanosti moždanih hemisfera i vrednosti latence i amplitude P300 kognitivnog potencijala. U istraživanje je uključeno 60 ispitanika starosne dobi od 45 do 56 godina ( $51 \pm 2,7$ godina). Bioelektrična aktivnost mozga registrovana je pomoću srebro-hlorid elektroda koje su postavljane na centralnoj liniji skalpa, frontalno (Fz) i centralno $(\mathrm{CZ})$ prema standardnom "10-20 međunarodnom sistemu". Za dobijanje P300 KEP korištena je "oddball” paradigma sa $80 \%$ standardnih stimulusa visine $1000 \mathrm{~Hz}$ i $20 \%$ ciljnih stimulusa visine $2000 \mathrm{~Hz}$. Obavljene su dve registracije, u prvoj registraciji su ispitanici reagovali desnom a u drugoj registraciji levom rukom. Svi ispitanici procenom upotrebne lateralizovanosti gornjih ekstremiteta su bili desnoruki. Na osnovu procene gestualne lateralizovanosti svi ispitanici su podeljeni u 3 grupe prema stepenu izražene desnorukosti. U grupi ispitanika sa snazno izraženim stepenom lateralizovanosti pri reagovanju sa dominantnom rukom vrednosti latenci P300 su statistički značajno kraće nad Fz elektrodom $(t=4,162, p<0,01)$ i nad $C z$ elektrodom $(t=5,302, p<0,01)$, a vrednosti amlituda P300 statistički značajno veće nad Fz elektrodom ( $t=-2,725, p<0,05)$ kao i nad $C z$ elektrodom $(t=2,527, p<0,05)$. S druge strane nema statistički značajne razlike u vrednostima latencija i amplituda $P 300$, između dominantne i nedominantne ruke $u$ grupi sa slabo i srednje izraženim stepenom lateralizovanosti kao ni u grupi sa prevežbanom lateralizacijom. $U$ obe posmatrane grupe zabeleženo je kraće reakciono vreme dominantnom rukom. P300 kognitivni potencijal i vreme reakcije mogu da doprinesu proučavanju pokazatelja funkcionalne asimetrije hemisfera mozga.

Ključne reči: P300, KEP, vreme reakcije, asimetrija hemisfera 